\title{
Migration as a Global Risk: The World Economic Forum and Neoliberal Discourse on Demography
}

\author{
ANDREU DOMINGO ${ }^{1}$
}

\begin{abstract}
Résumé
L'objectif principal de cet article est de rendre compte, du point de vue de la démographie, de la transformation du discours néolibéral sur l'immigration dans le contexte de la crise économique en Europe. Pour ce faire, l'article analyse, outre les sources secondaires pertinentes, les rapports annuels sur les risques globaux que le World Economic Forum a parrainé depuis 2006 jusqu'en 2015, afin de mesurer l'évolution d'un discours qui forge la perception des évolutions démographiques, et parmi elles la migration considérée comme un des risques majeurs à identifier, gérer et contrôler pour assurer une gouvernance mondiale. L'étude de ces rapports montre d'abord l'importance grandissante et dramatique que prend l'évolution démographique - à la fois en volume et en structure - au fur et à mesure de l'enfoncement dans la récession économique. Ensuite, la conception des migrations a connu un changement radical, présentées d'abord comme un problème puis comme une solution. Enfin, le discours néolibéral sur la gouvernance exprimée dans les mêmes termes que la gestion d'entreprise fait une nouvelle interprétation du concept de «résilience» et l'applique à des populations spécifiques.
\end{abstract}

\section{Mots-clés}

Démographie, migrations, risque global, résilience, néolibéralisme.

\begin{abstract}
The chief aim of this article is to give an account, from the standpoint of demography, of the transformation of neoliberal discourse on immigration since the onset of the economic crisis in Europe. The Global Risks reports published by the World Economic Forum from 2006 through to 2015 are analysed here, together with pertinent secondary sources, in order to gauge changes in a type of discourse that has been shaping perceptions of the evolution of population and, among related phenomena, migration as a major risk to be identified, managed and monitored in order to ensure global governance. Study of the reports shows, first, a progressive emphasis on demographic evolution as problematic - in terms of both volume and
\end{abstract}

1. Centre d'Estudis Demogràfics, Autonomous University of Barcelona. 
structure - as the economic recession has worsened. Second, the conceptualisation of migration has simultaneously undergone radical change in which it went from being a problem to becoming a solution. Finally, neoliberal discourse on governability, expressed in terms of business management, has reinterpreted the concept of «resilience» and applied it to specific populations.

\section{Key words}

Demography, migrations, global risk, resilience, neoliberalism.

\section{Demography, migrations and discourse analysis}

The chief aim of this article is to analyse, from the standpoint of demography, neoliberal discourse on migration since the onset of the economic crisis. If globalisation brought growth, acceleration and diversification of migratory flows, together with challenges presented by settling immigrant populations in host countries worldwide - all of which was reflected in growing interest in the matter and the proclaimed need for a political approach - the positions adopted in attempts at explaining migration seem to have been changing since the economic recession began. The focus on migration as a risk, within the theoretical framework of the Risk Society, is being substantially modified in favour of an increasing resort to the concept of resilience, which has been re-elaborated as a way of classifying populations along the business management approach and its use.

The eminently empirical nature of demography certainly works in its favour, giving it more credibility than other disciplines more subjected to speculation. Nonetheless, it is also at a disadvantage in being used all too often as an actuarial science by other disciplines with accredited theoretical baggage in order to analyse population statistics, to such an extent that there is a danger that the discipline of demography is disregarded, even when the discussion concerns intrinsically demographic matters. Before claiming that this is the result of intrusion, or blaming professionals who see demography as an exclusively applied form of knowledge, one should recognise that, since its very beginnings, it has been run through by two opposing axes. First is its vocation as a social science as opposed to that of policy-oriented science, as Dennis Hodgson (1983) warns. Second, as Michel Loriaux (2005) points out, there is a confrontation between «demometry» and «demology» in which the former refers to measurement of phenomena and their frequency, and the latter to the construction of theories starting from empirical observation. At the same time, demography is defined by the robustness of its 
quantitative methodology. Hence incursions from the field into qualitative analysis are relatively few and mostly limited to studying the discourse of individuals in order to understand demographic behaviour. Very few attempts have been made to understand the conceptualisation of demographic phenomena and their instrumental use in the political sphere, which is the aim of the present paper.

This article should be seen, then, as a first approximation in an ongoing project that aims to examine, from the standpoint of demography, the transformation that has been occurring in political, legal and fictional discussion of demographic evolution in general, and twenty-first-century migrations in particular. Its specific goal is to analyse changes in the concept of migrations as a risk, which is the scenario presented in neoliberal discourse after the onset of the 2008 economic crisis in Europe. The Global Risks reports, published annually from 2006 to the present by the World Economic Forum, are the main source used in this project since they provide a way of assessing the changes occurring in a discourse that is, in fact, shaping perceptions of population evolution in general, and migration in particular, as being among the key risks that must be identified, managed and monitored in order to ensure global governability. The findings of these reports are used in the present analysis as a discursive map on which to pinpoint the key concepts used in the neoliberal approach to migration.

In the following sections I shall give a more detailed account of this source and its approach to these issues, after which I shall analyse the discussion about population growth and structure in general, and then about migration in particular. The development of the concept of «resilience» as it appears in these reports and the way it is applied to population and migration will then be examined, a focus which, as I shall show, is essential for understanding this conceptual evolution.

\section{Sources and methodology}

The Global Risks reports have been published by the World Economic Forum (WEF) on an annual basis since 2006, always with support from private entities associated with insurance companies and research centres, or university departments specialising in the analysis of global risks. Founded in 1971 by Klaus Schwab, Professor of Business Policy at the University of Geneva, the WEF, «an international institution committed to improving the state of the world through public-private coopera- 
tion in the spirit of global citizenship» (www.weforum.org), is a nongovernmental organisation based in Cologny (Switzerland). While the original aim of the WEF was to foster the spread of American business culture in Europe, it has now become a key reference in global governance and, it might be said, one of the world's most influential generators of neoliberal thought and policy. One of its most conspicuous activities is the Davos Meeting in January each year, to which individuals deemed to be world leaders in different spheres (business, political and academic) are invited to discuss the perceived burning issues of the past year and those foreseen in coming years. It is also the occasion on which the annual Global Risks report is presented. The aim of these reports, as Klaus Schwab says in his Preface to the 2015 edition, has always been «to shed light on global risks and help create a shared understanding of the most pressing issues, the ways they interconnect and their potential negative impacts» (WEF, 2015, p. 6). The Introduction adds that for the past decade, the Global Risks report «has been calling attention to global risks and providing tools to support decision-makers in their efforts to mitigate or prevent global risks or strengthen resilience against them» (WEF, 2015, p. 10).

The ten reports published so far include among their backers the insurance companies Marsh \& McLennan and Swiss Reinsurance Company Ltd, together with the Wharton Risk Management and Decision Processes Center at the University of Pennsylvania. The latter is a research centre which promotes public policies to deal with risks of low probability but catastrophic consequences. In all the reports, Howard Kunreuther, Professor of Decision Sciences and Business Economics and Public Policy at the centre, appears as its representative. Merrill Lynch (active in Bank of America Merrill Lynch Healthcare Banking inter alia) participated in the 2006 report, as did Citigroup (which runs the world's largest financial services network and was the among the first companies to integrate financial and insurance services) in 2010, while the insurance company Zurich Financial Services has been involved since 2008.

On the academic side, the National University of Singapore and the Oxford Martin School at Oxford University have worked with the group in the last three years. It is noteworthy that part of the National University of Singapore team was trained at the Wharton Risk Center of the University of Pennsylvania. The Oxford Martin School is a prestigious institution specialising in risk forecasting and analysis. Prior to becoming its director in 2006, Professor Ian Goldin was well known in his career as a financial manager, vice-president of the World Bank (2003-2006) and, before that, Chief Executive and Managing Director of the Development 
Bank of Southern Africa (1996-2003). His recent work has focused on the role of demography as a tool for predicting the future with regard to migration (2011) and, subsequently, overpopulation (2014). However, the involvement of these two academic institutions has not entailed any substantial change in research methodology. Rather, they would seem to influence the conceptualisation and presentation of risk-related phenomena and risks themselves, and to underpin some areas in which different participants are specialists or have previously shown interest, for example Professor Goldin and his work on demographic phenomena.

The Global Risks reports are essentially based on analysis of the results of a global risk perception survey which is addressed to selected experts from the business, political and academic spheres - with numbers varying from 400 in 2006 to more than 700 in 2014 - who are asked about a number of previously identified global risks (between 25 and 50) in five different categories: economic, environmental, geopolitical, social and technological. They are asked to order them hierarchically, assess their probability and impact, and hypothesise relations among them over the coming ten years. The survey concludes with two open questions, the first concerning risks not envisaged in the questionnaire and, the second, about any additional issue that could potentially emerge as a serious risk of global concern in the future. The information thus gathered is processed in three main ways: establishing a hierarchy of risks, mapping their interconnections, and studying them in terms of impact and probability. Then there is a section on risks identified as either emerging or unanticipated.

It is not my intention to evaluate the adequacy of the methodology based on analysis of networks of concepts established for different scenarios according to the responses of the interviewees - or to consider the veracity of the data gleaned from the surveys on which the Global Risks reports are based, or even to examine the fit between data and interpretation. Instead, I shall analyse how discussion that shapes the presentation of this data ends up offering a specific image of population evolution as a risk or, in other words, transforming population evolution, structure and dynamics into a risk. This entails, first, analysing key population-related concepts starting from their context and, second, bringing to light the narrative line of this particular exposition. The underlying hypothesis of my approach is that the resulting account is geared to imposing ideas (in this case concerning demography), producing meaning and eventually influencing conduct (especially of policy makers) in a process that Salmon (2007) has called «storytelling» or, in 
other words, a re-conceptualisation of reality imposed by neoliberalism by dint of producing its own narrative technique.

A close look at the use of different population-related concepts may help to shed light on the shift in neoliberal discourse in the WEF reports on risk management, which is seen as the mainstay of global governability. In this case, "governability» should be understood as the set of devices that guarantee population management (Foucault, 1983). The message is not expressed in terms of a political position or economic theory but is manifested, rather, in the evaluation/construction of risk. This desire to present the findings of the reports as an «objective product» of scientific methodology, and the collective method of detecting possible risks by means of the aforementioned survey of experts are interesting because the concept of «discourse» whose «author» is embodied in a virtual individual - and here I would concur with the so called «anti-humanistic» perspective of Michel Foucault (1973) - does not figure anywhere as the unit of analysis in the WEF reports. It should also be pointed out that the reports never contemplate any analysis of the meaning of the experts' responses. Their opinions about present reality (and future trends) are the main source and taken as objectively characterising reality. This kind of analysis brings population evolution closer to the social imaginary, or a set of mental representations that end up informing and transforming social reality, as in the paradigm of the «imaginary institution of societies» described by Cornelius Castoriadis (1983).

\section{Population as a risk: Evolution of a concept}

In order to understand the evolution of the portrayal of population and migrations as a risk, one must - albeit briefly - refer to the theoretical framework of the Risk Society, where risk is understood as a future event that may appear as a threat. As a permanent menace, it determines our lives and expectations and therefore ends up invading our minds and governing our actions. The essential difference between this and catastrophe is temporal. The catastrophe has already happened, while risk is always lurking in the threat that something is going to happen and, accordingly, as a potential future event. Furthermore, risk needs some kind of staging in order to be perceived as such and also entails decision-making. This raises the question of who decides what constitutes a risk or, alternatively and in brief, who constructs the discourse that transforms a particular phenomenon into a risk (Beck, 2009). 
When Ulrich Beck formulated his risk society theory in 1986, he did so thinking about a more equitable distribution of the costs that might be occasioned by phenomena perceived by citizens and State as a risk. In this case, the State, as guarantor of security, shouldered responsibility for precautionary risk containment and distributing the costs of consequences and also expenditure deriving from individual decisions, while simultaneously making the individual participate in prevention. Evoking Ernst Bloch's The Principle of Hope, Beck remarked much later that development of his theory would imply a utopian viewpoint (Beck, 2013).

With hindsight, one can state that demographic evolution and, in particular, its growth has been conceptualised as a risk, at least since the publication of Thomas Robert Malthus' An Essay on the Principle of Population in 1798. Ever since then, it has never ceased to be perceived as a threat and a concern that is reflected in the emergence of dystopian theses produced by scientists and politicians alike. The most outstanding exponent here is Paul Ehrlich and his book The Population Bomb (1968). There have also been echoes in works of fiction (see Domingo, 2008), a recent example being Dan Brown's novel Inferno (2013). After the 1980s and the slowing of population growth, the evolution of population in general is still seen as a risk, or an unpremeditated or perhaps «natural» catastrophe - not unlike a tsunami - but also as an ambiguous phenomenon with disadvantages and benefits unequally distributed among different countries (depending on their situation in terms of demographic transition), between individuals and State in any one country (in accordance with the distribution of costs occasioned by a catastrophe), and also among individuals (in keeping with basic sociodemographic characteristics such as gender, age, origin, situation in the family cycle or household structure and employment).

Among the demographic factors perceived as risks, I would emphasise three in particular: 1) population growth; 2) structure by age; and 3) migrations. The hegemonic discourse has labelled immigration as an erroneous (or insufficient) solution to the challenge presented by population ageing, as argued in the controversial report published in 2000 by the United Nations Population Division, Replacement Migration, Is It a Solution to Declining and Ageing Populations? Despite all the provisos offered by the authors and a considerable range of forceful criticisms of the report's point of view (Coleman, 2001; Weiner, Teitelbaum, 2001, inter alia), migration is still generally presented either as a palliative to the relative scarcity of young people, a view which places population ageing under the heading of natural catastrophe, or a response to the 
inability of national labour markets to absorb them in countries which have relatively new infrastructures.

Along these lines, one finds opinions by individuals who are both well known and, in ideological terms, very different (Domingo, 2014), ranging from the most conservative proponents of Malthusianism like Giovanni Sartori and Gianni Mazzolenni (2003) through to individuals voicing different opinions in the ecologist movement, amongst whom one might cite the renowned author James Lovelock (2007 and 2010) and, in recent years, coinciding with the fact that the world's population now exceeds the figure of seven billion inhabitants, new writers such as Stephen Emmott (2013), to name just a few. As for studies directly addressing migration, one could single out such works as Jean-Claude Chesnais' Le crépuscule de l'Occident. Démographie et politique (1995), or Samuel Huntington's influential clash-of-civilisations (populations) paradigm (1993, 1996 and 2004).

The Global Risks reports give the impression that the evolution of population has become an increasingly pressing concern. This is partly due to the fact that the three demographic factors I have mentioned above were always hovering in the background of global risks studies. Moreover, before the present crisis, the immediacy and repercussions of other risks had eclipsed demographic phenomena which were characterised more by their power of inertia, especially with regard to growth and structure, than by any prognosis of their spectacular nature or impact ten years on. In any case, demographic evolution does not appear to have been listed as one of the five top risks until 2009 when it appears specifically with regard to immigration and under the «Social» heading.

In order to offer a clear illustration of the evolution and treatment of demographic phenomena in the different WEF reports, Table 1 takes material from 2007 to 2015 showing the most serious risks in terms of probability and impact every year. Probable risks are first classified as «societal risks» (including demographic risks) and eventually demographic phenomena appear as risks per se. Before discussing this evolution, I would point out that information about the risks identified in each edition as well as their place in the hierarchy is patchy and unsystematic, so the approximation offered by Table 1 is quite partial. For example, in years when demographic phenomena do not appear in the first five places of the hierarchy of risks, there is no exact description of the place they occupy. Neither is there any systematic information regarding when and how the most serious risks are related with demographic phenomena, unless this is specifically mentioned in the reports. 
The first thing one sees is that, like public opinion in general, the experts' views tend to reflect the impact of the most momentous phenomena of the previous year. Hence, the avian influenza pandemic appeared in the 2007 report as a pre-eminent social risk in terms of impact, asset price collapse headed the list of concerns in the three years following the onset of the crisis while, in the 2015 report, «interstate conflicts with regional consequences» (p.16) in Syria and Ukraine was a paramount risk. It is possible that, since the surveys for each report are carried out at the beginning of the year, thus embracing the newsworthy events of the previous year, the 2016 report will again feature fear of pandemics among social risks owing to the gravity and repercussions of the outbreak of Ebola virus disease at the end of 2014 (which appears in the 2015 report). This said, it should be noted that demographic phenomena appeared for the first time as risks in their own right in the 2008 report (with regard to ageing), in 2009 (referring to migration) and in 2011 (as a general «likelihood» issue dubbed «demographic challenges»). Prior to this, their presence was al-ways subsidiary, cited as a cause or consequence of some non-demo-graphic risk. For example, population growth (or density) systematically appears in relation with environmental risks as an aggravating factor of extreme weather, water scarcity or biodiversity loss, to give a few outstanding examples, or when, in the domain of economics, the risk of «retrenchment from globalization» might mean «increased hurdles to cross-border labour migration», or the financial crisis could be exacerbated by the age structure of the population (WEF, 2010).

An overview of the treatment of population from the standpoint of its evolution in the ten years between the publication of the 2006 report and that of 2015 shows two striking trends: 1 ) the divergent paths taken in evaluating population growth and the imbalances presented by both its structure by age and migration; and 2) changes in the ways in which these phenomena are considered, especially the drastic change, if not total turnaround, in the treatment of migrations as a factor of risk. If population ageing and migrations were seen as potential risks per se in 2008 and 2009 respectively, after 2012, it is specified that, rather than constituting risks in themselves, the real risk is bad management of both phenomena. In 2015, however, they appear as «trends», although they also remain as subsidiary factors among risks classified as most probable or of greatest impact, especially with regard to population growth in the cases of the water crisis and migration related with interstate conflict. 
TABLE 1 Demography and evolving risk: An overview (2007-2015)

\begin{tabular}{|c|c|c|c|c|c|c|c|c|c|}
\hline & 2007 & 2008 & 2009 & 2010 & 2011 & 2012 & 2013 & 2014 & 2015 \\
\hline Likelihood & $\begin{array}{l}\text { Breakdown } \\
\text { of critical } \\
\text { informa- } \\
\text { tion infras- } \\
\text { tructure }\end{array}$ & $\begin{array}{l}\text { Asset price } \\
\text { collapse }\end{array}$ & $\begin{array}{l}\text { Asset price } \\
\text { collapse }\end{array}$ & $\begin{array}{l}\text { Asset price } \\
\text { collapse }\end{array}$ & $\begin{array}{l}\text { Storms and } \\
\text { cyclones }\end{array}$ & $\begin{array}{l}\text { Severe in- } \\
\text { come dis- } \\
\text { parity }\end{array}$ & $\begin{array}{l}\text { Severe in- } \\
\text { come dis- } \\
\text { parity }\end{array}$ & $\begin{array}{l}\text { Income dis- } \\
\text { parity }\end{array}$ & $\begin{array}{l}\text { Interstate } \\
\text { conflicts } \\
\text { regional } \\
\text { conse- } \\
\text { quences }\end{array}$ \\
\hline Impact & $\begin{array}{l}\text { Asset price } \\
\text { collapse }\end{array}$ & $\begin{array}{l}\text { Asset price } \\
\text { collapse }\end{array}$ & $\begin{array}{l}\text { Asset price } \\
\text { collapse }\end{array}$ & $\begin{array}{l}\text { Asset price } \\
\text { collapse }\end{array}$ & Fiscal crisis & $\begin{array}{l}\text { Major sys- } \\
\text { temic fi- } \\
\text { nancial } \\
\text { crisis }\end{array}$ & $\begin{array}{l}\text { Major sys- } \\
\text { temic fi- } \\
\text { nancial } \\
\text { crisis }\end{array}$ & Fiscal crisis & $\begin{array}{l}\text { Water cri- } \\
\text { sis }\end{array}$ \\
\hline $\begin{array}{l}\text { 1st societal } \\
\text { risk (likely- } \\
\text { hood) }\end{array}$ & $\begin{array}{l}\text { Chronic } \\
\text { deseases in } \\
\text { developed } \\
\text { countries }\end{array}$ & $\begin{array}{l}\text { Chronic } \\
\text { deseases in } \\
\text { developed } \\
\text { countries }\end{array}$ & $\begin{array}{l}\text { Chronic } \\
\text { deseases }\end{array}$ & $\begin{array}{l}\text { Chronic } \\
\text { deseases }\end{array}$ & $\begin{array}{l}\text { Demo- } \\
\text { graphic } \\
\text { challenge }\end{array}$ & $\begin{array}{l}\text { Severe in- } \\
\text { come dis- } \\
\text { parity }\end{array}$ & $\begin{array}{l}\text { Misman- } \\
\text { agement of } \\
\text { population } \\
\text { ageing }\end{array}$ & $\begin{array}{l}\text { Income dis- } \\
\text { parity }\end{array}$ & $\begin{array}{l}\text { Interstate } \\
\text { conflicts } \\
\text { regional } \\
\text { conse- } \\
\text { quences }\end{array}$ \\
\hline $\begin{array}{l}\text { 1st societal } \\
\text { risk (im- } \\
\text { pact) }\end{array}$ & Pandemics & Pandemics & $\begin{array}{l}\text { Chronic } \\
\text { deseases }\end{array}$ & $\begin{array}{l}\text { Chronic } \\
\text { deseases }\end{array}$ & $\begin{array}{l}\text { Water } \\
\text { scarcity }\end{array}$ & $\begin{array}{l}\text { Food shor- } \\
\text { tages cities }\end{array}$ & $\begin{array}{l}\text { Water sup- } \\
\text { ply crisis }\end{array}$ & $\begin{array}{l}\text { Income dis- } \\
\text { parity }\end{array}$ & $\begin{array}{l}\text { Water } \\
\text { crisis }\end{array}$ \\
\hline \multirow[t]{3}{*}{$\begin{array}{l}\text { Demogra- } \\
\text { phy }\end{array}$} & & $\begin{array}{l}\text { Ageing po- } \\
\text { pulation in } \\
\text { developed } \\
\text { countries }\end{array}$ & Migration & Migration & $\begin{array}{l}\text { Population } \\
\text { "cluster } \\
\text { bombs" }\end{array}$ & $\begin{array}{l}\text { Misman- } \\
\text { agement of } \\
\text { population } \\
\text { ageing }\end{array}$ & $\begin{array}{l}\text { Misman- } \\
\text { agement of } \\
\text { population } \\
\text { ageing }\end{array}$ & $\begin{array}{l}\text { Misman- } \\
\text { agement of } \\
\text { population } \\
\text { ageing }\end{array}$ & $\begin{array}{l}\text { Large-scale } \\
\text { involuntary } \\
\text { migration }\end{array}$ \\
\hline & & & & & $\begin{array}{l}\text { Global } \\
\text { graying }\end{array}$ & $\begin{array}{l}\text { Unman- } \\
\text { aged mi- } \\
\text { gration }\end{array}$ & $\begin{array}{l}\text { Unman- } \\
\text { aged mi- } \\
\text { gration }\end{array}$ & $\begin{array}{l}\text { Unman- } \\
\text { aged mi- } \\
\text { gration }\end{array}$ & $\begin{array}{l}\text { Ageing po- } \\
\text { pulation } \\
\text { (trend) }\end{array}$ \\
\hline & & & & & $\begin{array}{l}\text { Demo- } \\
\text { graphic } \\
\text { dividends }\end{array}$ & $\begin{array}{l}\text { Unsustain- } \\
\text { able popu- } \\
\text { lation } \\
\text { growth }\end{array}$ & $\begin{array}{l}\text { Unsustain- } \\
\text { able popu- } \\
\text { lation } \\
\text { growth }\end{array}$ & $\begin{array}{l}\text { Unsustain- } \\
\text { able popu- } \\
\text { lation } \\
\text { growth }\end{array}$ & $\begin{array}{l}\text { Rising geo- } \\
\text { graphic } \\
\text { mobility } \\
\text { (trend) }\end{array}$ \\
\hline
\end{tabular}

Note: In the years 2008, 2011 and 2015 demographic phenomena appear as general trends or potential risks to watch, although «Migration» in 2011 and its reformulation as «Unmanaged migration» in 2015 remain present. The same might be said of population ageing.

Source: Compiled by the author from the World Economic Forum' Global Risks reports 2007 to 2014.

\section{Population growth and structure: The malthusian view}

The construction of population growth as a factor of risk remains within the framework of Malthusian orthodoxy, which suggests a long-standing mismatch between the expanding population and the investment in agriculture deemed necessary to increase productivity and meet the demand for food occasioned by this growth. In the short term, it is presented as a threat to biodiversity and the sustainability of ecosystems, although this is qualified by the observation that the danger lies in the combined factors of population growth and continuance of current patterns of consumption. The eventual constant element was that population growth appeared as pressure on resources with clear repercussions expressed in concepts such as «food security» (WEF, 2008), rising greenhouse gas emissions related with climate change (WEF, 2009, p. 16), political instability (with particular reference to Afghanistan) and stress on water resources (WEF, 2010, p. 8). Population growth and economic evolution are listed as detonating factors or multipliers of further risks, mainly in the countries with emerging economies (WEF, 2011). The high point of this line of thought came with the 2012 report 
when demographic evolution itself in conjunction with fiscal risks was presented as a «seed of dystopia» (WEF, 2012, pp. 16-19), a concept that was probably underpinned by the UN-orchestrated media staging of population growth when 30 October 2011 was selected as the «official» birthday of the world's seven billionth inhabitant. In the 2014 Global Risks report, urban population takes over the limelight from global population, with the concomitant assumption that urbanisation will give rise to increasingly serious ecological risks as well as growing inequality and worsening political instability (WEF, 2014).

As for structure, distinction must be made between two phenomena, first, population ageing and, second, the relationship between demographic structure, economic development and governability on the global scale. Two different aspects of population ageing have been taken into account throughout this period, namely its impact on the social security system in general and increased health sector costs in particular. In the former case, population ageing is singled out as a risk in discussion of the effects of the financial crisis and unemployment in social security systems. The need for a new social contract taking intergenerational transfers as its reference point is now proclaimed, while the nonsustainability of the pension system owing to the population age structure is stressed. Hence the issue of ageing is ushered into the 2010 report in the context of the financial crisis and under the heading «The implications for social systems: a new social contract for the 21st century?» (WEF, 2010, p. 14). According to the authors of the report, this breakdown of the system, which was anticipated prior to the crisis with causes also preceding it, requires a redistribution of future costs. In other words, costs must be shared between individuals and the State, which is to say between the public and private sectors. Cognizant that such measures will be unpopular, the report continues, «The costs of social safety nets will have to be better shared among the population and the expectations of people in terms of health and pensions will have to be realigned. This may require politicians to implement unpopular decisions at a time when voters are suffering from the hardship of high unemployment caused by the global recession» (WEF, 2010, p. 14). However, there is no mention of what these measures might be. With regard to health in particular, progressive ageing is held responsible for rising health sector costs associated with the morbidity (chronic illnesses) and mortality characterising what is now dubbed a «silent» pandemic (WEF, 2010 , p.24). Ageing in the developed countries will continue to be viewed as the sword of Damocles hanging over present and future generations because of the "rising challenge of fiscal stress caused by unfunded liabilities linked to ageing societies», thus jeopardising the sus- 
tainability of social security (WEF, 2011, p. 19). Although it is asserted that, when properly managed, ageing can also be seen as an opportunity for society and businesses, it is also claimed more specifically that the sustained rise in longevity and upward trend in obesity levels constitute a burden because of their contribution to increasing public health costs and their repercussion in terms of pensions (WEF, 2014).

Finally, I would emphasise that, since the 2011 report, the linking-up of possible risks arising from age-based structures of the population with economic development has been ever more apparent. Besides global ageing, the effects of the "demographic dividend» for economically emerging countries with regard to the sustainability or otherwise of a growing number of working-age individuals and, in particular, the progressive entry of young people into the job market, are henceforth taken into account. This perspective coincides with a geopolitical distribution which, considering the situation of each country in terms of demographic transition, has been presented by some writers, for example Jack A. Goldstone (2010), who in some ways call into question the Huntington paradigm of The Clash of Civilizations based on virtual ethno-cultural categories distinguishing between developed (post-transitional) countries, those with emerging economies (in the process of transition), and developing (pre-transitional) economies, as was recently reflected in the 2012 report. The different demographic contexts thus identified find a nexus in migration, starting with flows of people from country to city, and continuing with international migration. The absence of adequate channels (which is to say policies) for regulating the surplus of young people and the demand for them is identified as the leading cause of irregular migration. Hence, some ambivalence is evident when it comes to evaluating migration, which can be viewed as a remedy (for both emitting and host countries), or a complication.

\section{Migrations: From problem to solution}

As I have remarked above, the 2009 report - in which a notable feature is awareness of the global nature of the economic crisis and the need, therefore, to revamp the financial structure and also prevent «overregulation» (p. 3) - is the first to pigeonhole a demographic phenomenon, and migrations in particular, as pre-eminent risks. In this report, the only information explicitly presenting migratory movements as a risk - whether with regard to illegal workers or movements of refugees - is a disturbing association with terrorism and direct military conflict (WEF, 2009, p. 24). Similarly, Table 1 shows that, after 2012, «Mis- 
management of population ageing» replaces the earlier concept of «Age structure», while «Migration» becomes «Unmanaged migration», which the report defines as «Mass migration driven by resources scarcity, environmental degradation and lack of opportunity, security or social stability» (p. 43). This subtle shift from phenomenon itself to managementof-phenomenon opens the door to another perception which could give a completely different meaning to migration and population ageing, even while they are still portrayed as potential risks.

An abyss yawns between this highly negative perception and the position that appears after 2012, which ends up presenting migration as a solution in the 2014 report. What brought about this change? In the short term, it may be seen as a response to the immediate effects of the crisis. One explanation lies with rising migratory pressures after the Arab Spring and evidence of the inability of the European Union to satisfy the demand, thus jeopardising the Schengen Agreement. Then again, there is awareness that emigration is an understandable response to inefficient systems of production in developing countries which fail to absorb the young population in excess. It is also noted that developed countries like Spain, Greece, Portugal and Italy which, particularly affected by unemployment caused by the economic crisis, have «empty» young generations because they have gone back to being migrant exporters. In the long term, unavoidable population ageing has again raised the need - once the crisis is over - to acquire a workforce, a potential that already appears as a trend in the case of the highly skilled workforce. This, in fact, is leading to substantial competition between different parts of the developed world and a growing demand foreseen for the emerging economies (presently viewed as possible exporters).

The risk here is the misfit between migratory movements resulting from unemployment and, in both countries of origin and host countries, policies pertaining to migration and development aid. The toughening of migration policies during the years of crisis and the expanding informal sector are taken as factors that swell the ranks of illegal immigrants as well as presenting long-term obstacles to filling jobs in some sectors because of a shortage of workers with certain levels of training when the envisaged economic recovery occurs. It is suggested that policies encouraging the «return of the educated diaspora as a tool for development or making the ability of countries to attract immigrants a badge of success» (WEF, 2010, pp. 16-17) should be considered. One of the more stalwart proponents of the positive view of migration which has been gaining ground in the reports since 2012 is the Professor of Globalisation and Development and Director of the Oxford Martin School, Ian 
Goldin, who has been one of the authors of the reports since 2012. Goldin sees migration as a mechanism for rectifying economic inequalities (Goldin, 2014) and, from this standpoint, considers that the best way of correcting «unmanaged» or «mismanaged migration» is none other than the need for "global leadership» capable of imposing a liberal agenda that will guarantee the priority of free movement over «national» interests (Goldin, 2011).

Special attention should be given to the question of the «lost generation», generally defined by the economic parameter since its members are victims of the crisis while still young. They are also characterised by the technological variable because they are the first generation of «digital natives». Rising education costs, increasing unemployment and job insecurity, as well as the impact of all this on careers are the main threats they must face. Once again, the variety of demographic and economic contexts is discussed in order to understand the situations of different groups of young people: in the developed countries (where the risk is rupture of the intergenerational social contract), in emerging countries (where the impact seems somewhat mitigated, although the growing urban population and the leap from tradition to ultra-modernity means a generational standoff) and, finally, in developing countries (in which frustrations among young people arising from the gap between expectations and the actual job offer, combined with political conditions, typify situations of the kind that led to the Arab Spring). Although the relative scarcity of young people and its possible effects on the future demand in the job market may appear in the medium and long term as a solution for young workers in future, the youth of today seems condemned to instability, low wages, scant productivity and the informal economy. Accordingly, political instability is raised as a WEF concern. Now, for the first time, migration is presented more as a solution than as a problem, although with two major provisos: it applies to highly skilled workers and is also subject to the subsequent return of skilled emigrants to their countries of origin (WEF, 2014, p. 38). As Massimo Livi-Bacci (2010) warns, advocating temporary and circular migration as the only solution, presented as a way of maximising remittances and combating the brain drain and thus appeasing the countries of origin, also means curbing the migrant's freedom, obstructing settlement in the host country and, incidentally, cutting back on every possible social service cost. 


\section{From prevention to resilience}

The geographer Ash Amin (2012) has pointed out how, during the first decade of the twenty-first century, discussion about the Risk Society has significantly changed with a shift from «prevention» to "resilience». Instead of situating contemporary societies as belonging to a welfare economy emphasising economic progress and equitable redistribution of benefits and costs, as Ulrich Beck advocated, the new neoliberal logic views populations and individuals from a narrower perspective of their contribution to competition on a global scale and what they cost. This framework, which draws on completely opposing political traditions to define both risk society and resilience, in fact expresses a deeper-rooted position advocating lines of deregularisation which began with the crisis of 1973. In Amin's opinion, acceptance of this stance would have been favoured by a whole series of natural and social phenomena understood as catastrophes, starting with terrorist attacks (11 September 2001, Madrid 2004, London 2005), natural disasters (the tsunami that lashed the coasts of Southeast Asia in December 2004, Hurricane Katrina in New Orleans in August 2005, the eruption of the volcano in Iceland in 2010 and the nuclear crisis resulting from the tsunami that hit the coasts of Japan in March 2011), and the avian influenza epidemics between 2004 and 2006, together with the effects of the financial crisis following the bankruptcy of Lehman Brothers in 2008, all of which have played their part in this change of discourse. Given the proliferation of risks and the difficulties of long-term prediction, the new standpoint now accepts them as inevitable, endowing them with a catastrophic character and turning to strategies of minimisation and mitigation instead of prevention and avoidance. In Ash Amin's view, use of the concept of resilience in this context moves away from a focus on the protected society towards a self-defence society in which citizens and public organisms appear as agents of intervention, knowledge managers and architects of reconstruction.

The World Economic Forum Global Risks reports provide a splendid compass for anyone wishing to monitor the drift of the shift. The term «resilience» appears in the 2006 report as a strategy of risk mitigation applied in equal measure to both institutions and society without identifying any population in particular. The concept of resilience appears in the Introduction as an undefined strategy (which remained undefined until 2012, as noted below) for mitigating future risks by «strengthening the capacity and resilience of business and political and administrative institutions at all levels» (WEF, 2006, p. 1). «Mitigation» is identified 
here as the first response to global risks, in the understanding that, "Mitigation covers a range of actions, from prevention - where possible - and preparation for risk events» (WEF, 2006, p. 9). From the very beginning, it is clearly linked with private sector participation: «[T]here is scope for more widespread and effective initiative by the private sector. Incentives need to be properly aligned to make risk mitigation as much about proactive prevention as about reactive recovery» (WEF, 2006, p. 1). This report also contains the only development of the idea of resilience as a capacity to be promoted in the business world in particular (p. 13).

This is a management strategy based more on the way the concept of resilience has been developed from the business perspective than on the way it was reshaped as it moved from physics (analysis of the behaviour and property of specific materials) into the social sciences (MartinBreen, and Anderies, 2011). It reappeared in the market context (identifying the resilience of exports as a way of trying to counterbalance the disruption of the financial markets), referring to the financial system itself (as the capacity to resist both the buffeting of the crisis and as a way of returning to the previous «normality» or finding a new balance), to the proper management of chains of distribution (WEF, 2008), to the effectiveness of fiscal or monetary responses, and to governance and regulation (WEF, 2010). It is only when dealing with climate change that it acquires a national dimension but, even so, «resilience» always refers to the economy and not populations. It is linked with the population only indirectly, in the discussion about how much needs to be invested in infrastructure when considering the dependence of the population and organisations on its proper functioning. It is clear, however, that the overriding concern is always the resilience of the system (WEF, 2010, p. 13).

The 2013 report is all about resilience and now, for the first time, this extends to the whole planet from the environmental perspective. More important, a special section is devoted to national resilience. The metaphor used, that of the "perfect storm», synthesises the overriding concern of the clash between economic risks (resulting from the economic crisis) and environmental risks (aggravated by the effects of the economic crisis) and - ignoring the connection between them - resilience at the national level. For the first time, too, an attempt is made to define the concept of resilience in more detail, recognising its origins in engineering and its diffusion into many other scientific disciplines - without going any deeper than that - to end up expanding the definition that had previously been given in the 2012 report so that, in the 2013 report, a 
resilient country becomes «one that has the capability to 1) adapt to changing contexts, 2) withstand sudden shocks and 3) recover to a desired equilibrium, either the previous one or a new one, while preserving the continuity of its operations» (WEF, 2013, p. 37).

The growing prominence of the concept of «resilience» reached a peak in the 2014 report when, starting from its executive summary, resilience and its construction appear as the ultimate aim of this and subsequent reports. Resilience is viewed primarily as the product of good government, understood as proper management of factors of risk. The development of the concept is closely linked with that of vulnerability, with special attention to populations. The emphasis on young people and minorities as particularly vulnerable, at least in terms of employment since the onset of the economic crisis, changes to an accent subsequently given to the so-called «lost generation»- approximately defined as the cohort aged between 13 and 23 in 2013 - and also, but much less categorically and only sketchily, to policies aimed at integrating migrant populations into the urban population (WEF, 2014, p. 33). Resilience is no longer viewed as exclusively referring to the economic system or as an integral part of it but it is now also applied to a human population. In other words, referring to the «lost generation»- explicitly mentioning young people from the Middle East and also from Spain and Greece - the diagnosis leads to a series of measures aimed at rescuing or, in other words, «building the resilience» of these people. The first of these measures is reform of the educational system, which means extending schooling for young people in developing countries, and revamping university syllabuses in developed countries with a view to enhancing competitiveness. Also mentioned as a desirable aim in this sphere is working with the private sector, which, the authors say, should make it easier for young people to find jobs and put an end to over-qualification and precarious working conditions (WEF, 2014, p. 35). The second proposal is that leaders should change their approach so as «to find ways to engage the young generation», which is described as distrusting authorities and institutions: «Anti-austerity movements and other protests give voice to an increasing distrust in current socioeconomic and political systems. The young are an important constituent of the general disappointment felt in many nations with regional and global governance bodies such as the EU and the International Monetary Fund (IMF)» (WEF, 2014, p. 36). This programme geared to fostering the participation of young people in social and political institutions then presents their present precarious situation as a product of intergenerational tension caused by growing numbers of old people and the corresponding pressure on welfare systems. The problem is formulated in the form of 
questions: «What can be done to mitigate intergenerational tension arising from demographic and economic pressures on welfare systems? How can the millennial and post-millenial generations be socially better protected?» (WEF, 2014, p. 37). The third solution suggested for young people in - ageing - developed countries is changing the pension system (without specifying how) while, for developing countries and those of the south of Europe subject to austerity policies, better management of circular migration is recommended.

\section{Discussion: liaisons dangereuses}

It is essential that today's demographers should try to break free of the web of discourse that is being woven around population in general and migrations in particular. If they do not, neoliberal versions will continue to hold sway in the struggle for ascendancy over meanings in scientific production, subordinating demography and relegating it to the position of an auxiliary discipline, while appropriating the intelligibility of demographic processes and moulding them to justify their own arguments.

The casting of population evolution in the role of catastrophe is part and parcel of an approach by means of which neoliberal discourse has sought to use demographic structure and dynamics to give a veneer of legitimacy to the imposition of its policies and disciplinary practices (Laval, Dardot, 2009). In the story told by the neoliberal economist, population ageing appears as a risk that is being passed on to coming generations owing to decisions made by individuals not to have «enough» children for their own generation, as does inadequate distribution between the individual and the State of responsibility for social costs, especially pensions. Migration, which at the start of the millennium was presented as a necessary evil, and not sufficient for correcting population ageing, became a solution after the onset of the economic crisis, although still showing clearly skewed bias with regard to the migrant's country of origin and professional skills. This, of course, overlooks the fact that migration is not only about demand for highly skilled individuals, but it is also a matter of individual will (and, accordingly, human rights). The latter aspect has disappeared into the mesh of interests linking the migrants' states of origin and the host countries.

In this context, «resilience» appears clearly as a matter of «governance» which, from the WEF standpoint, means calling for global institutions. Applied to populations in general and migrants in particular, «resili- 
ence» is a matter of classification or, if one prefers, political decisionmaking which, as in the case of the «lost generation», has chosen to focus more on one vulnerable group than on others. Migration can appear as a factor of resilience in itself but, once again, this approach is framed in political discourse that singles out one type of migrant and overlooks others. However, this about-turn in the way in which migration is conceptualised introduces a more disciplinary element, namely control as part of migration policies - control of individuals, their mobility, and responsibility for themselves being the first target - but always in the context of «old policies» adopted by the EU in which migration is seen exclusively within the framework of the needs of the market, oscillating between the proclaimed desire for integration and a progressive hardening of policy.

If we do not wish demography to be instrumented by neoliberalism, we must uphold the discipline's own discourse on the basis of theoretical development which requires the effort of radical, informed criticism of any instrumental use being made of it. A project of this scope would have to start with three steps. The first would entail the theoretical effort of thinking in genealogical terms about the origins and evolution of demography as a discipline. This would perforce involve a critical review of the concepts and categories used, starting with «population» and «reproduction» (demographic and social). It also means bringing to light from the demographic standpoint concepts which, while they do not strictly pertain to the discipline, are used when thinking about managing populations. «Resilience» is an outstanding example. Second, the task of empirical measurement and definition of notions like «lost generation» which are imposed as «demographic realities» should be carried out by demographers. This would require comparative analysis both between different countries and at different points in time. In the case of a generation, one would have to compare the number of people involved, the composition of this generation in comparison with others and the same generation in other countries. Third and finally, thoroughgoing criticism of neoliberal discourse from the standpoint of demography would presuppose analysis of the mode of scientific production imposed on the social sciences in general by the neoliberal framework. I refer to a situation in which academics are expected to approach their research in accordance with "the demands of the market» and must therefore adjust research activity to the competition, subordination to the private sector in terms of funding, and evaluation in terms of its ability to produce short-term benefits or its justification as ideological discourse assessed by its media impact. 


\section{References}

Amin A. (2012), Land of Strangers, Cambridge, Polity Press.

BECK U. (1986), Riskogesellshaft. Auf dem Weg in eine andere Moderne, Suhrkamp Verlag.

BECK U. (2009), World at Risk, Cambridge, Polity Press.

BeCK U. (2013), German Europe, Cambridge, Polity Press.

BLoch E. (1998), The Principle of Hope, Chicago, MIT Press.

BRown D. (2013), Inferno, New York, Doubleday.

CAstoriadis C. (1983), L'institution imaginaire de la société, Paris, Éditions du Seuil.

Chesnais J.-C. (1995), Le crépuscule de l'Occident. Démographie et politique, Paris, Robert Laffont.

Coleman D. A. (2001), «Replacement Migration, or Why Everyone Is Going To Have to Live in Korea: A Fable for Our Times from the United Nations», The Royal Society, 357, pp. 583-598.

Domingo A. (2008), «Demodystopias: Prospects of Demographic Hell», Population and Development Review, 34 (4), pp. 725-745.

Domingo A. (2014), "Demography as a Seed of Dystopia», Papers de Demografia, (432).

Ehruch P. R. (1968), The Population Bomb, New York, Sierra Club.

Eммотт S. (2013), Ten Billion, London, Penguin.

Foucault M. (1973), El orden del discurso, Barcelona, Tusquets.

Foucault M. (1983), Resumé des cours 1970-1982, Paris, Julliard.

GolDIN I. (2011), Exceptional People: How Migration Shaped Our World and Will Define Our Future, Princeton, Princeton University Press.

Goldin I. (2014), Is the Planet Full?, Oxford, Oxford University Press.

Goldstone J. A. (2010), «The New Population Bomb. The Four Megatrends That Will Change the World», Foreign Affairs, January/February.

Hodgson D. (1983), «Demography as Social Science and Policy Science», Population and Development Review, 9 (1), March, pp. 1-34.

Huntington S. P. (1993), «The Clash of Civilizations», Foreign Affairs, 72 (3), pp. 2249.

Huntington S. P. (1996), The Clash of Civilizations and the Remaking of World Order, New York, Simon and Schuster.

Huntington S. P. (2004), Who are We? The Challenges to America's National Identity, New York, Simon and Schuster. 
Laval C., DaRdot P. (2009), La nouvelle raison du monde, Paris, Éditions la Découverte.

LIVI-BACCI M. (2010), In cammino. Breve Storia delle migrazione, Milan, II Mulino.

LORIAUX M. (2005), Questions de méthode et méthodes en question. Réflexions sur les conditions de la recherche dans les sciences de la population et sur leurs apports à la compréhension de l'évolution des sociétés humaines, Louvain-la-Neuve, Presses universitaires de Louvain, Thèses de la Faculté des sciences économiques, sociales, politiques et de communication, $234 \mathrm{p}$.

Lovelock J. (2007), The Revenge of Gaia, London, Penguin Books.

Lovelock J. (2010), The Vanishing Face of Gaia, London, Penguin Books.

Martin-Breen P., Anderies J. M. (2011), Resilience: A Literature Review, The Rockefeller Foundation.

SALMON C. (2007), Storytelling, la machine à fabriquer des histoires et à formater les esprits, Paris, La Découverte.

SARtori G., MazzolenNı G. (2003), La terra scoppia. Sovrapopulaziione e sviluppo, Milan, Rizzoli.

United Nations (2000), Replacement Migration, Is It a Solution to Declining and Ageing Populations?, Population Division, Department of Economic and Social Affairs.

Weiner M., Teitelbaum M. S. (2001), Political Demography, Demographic Engineering, New York, Oxford, Berghahn Books.

World Economic Forum (2006), Global Risks 2006, Geneva.

World Economic Forum (2007), Global Risks,2007, Geneva.

World Economic Forum (2008), Global Risks,2008, Geneva.

World Economic Forum (2009), Global Risks 2009, Geneva.

World Economic Forum (2010), Global Risks 2010, Geneva.

World Economic Forum (2011), Global Risks 2011, Geneva.

World Economic Forum (2012), Global Risks 2012, Geneva.

World Economic Forum (2013), Global Risks 2013, Geneva.

World Economic Forum (2014), Global Risks 2014, Geneva.

World Economic Forum (2015), Global Risks 2015, Geneva. 